\begin{tabular}{lc}
\hline CURRENT & ISSN: 0973-4929, Vol. 12, №. (2) 2017, Pg. 377-388 \\
WORLD & Current World Environment
\end{tabular}

ENVIRONMENT Journal Website: www.cwejournal.org

\title{
A Status of Invasive Alien Species Plant diversity in Tehri District Forest Ecosystem of Garhwal Himalayan Region
}

\author{
ARTI KHANDURI ${ }^{1}$, SAS BISWAS ${ }^{2}$, H.B. VASISTHA ${ }^{3}$, \\ DIGVIJAYSINH RATHOD ${ }^{4 *}$ and SUMAN KUMAR JHA ${ }^{5}$
}

'Department of Forestry, Doon (P.G) College of Agriculture Science and Technology, Dehradun, India.

${ }^{2}$ Department of Forestry, Dolphin (PG) Institute of Biomedical and Natural Science, Dehradun, India

${ }^{3}$ Ecology and Environment Division, Forest Research Institute, Dehradun, India.

${ }^{4}$ Silviculture Division, Forest Research Institute, Dehradun, India.

${ }^{5}$ Department of Forest Biology and Tree Improvement, College of Forestry, Navsari

Agricultural University, Navsari, India.

\begin{abstract}
Invasive alien species that is non-indigenous to an area, and which may have harmful effect on human, animal, plant health as habitat destruction, degradation and fragmentation of ecosystems. During the study observed the present status of plant diversity of invasive alien species (IAS) in Tehri District of Garhwal Himalaya, Uttarakhand. Data were collected through extensive field survey and quadrat method. Result observed that 75 Forest Invasive Species (FIS) and 47 weed species documented from the area. Among the 75 FIS, 12 species belonging from Asteraceae, 7 species from Poaceae, 7 species of Solanaceae, 5 species of Lamiaceae, followed by four species of each Ranunculaceae and Polygonaceae while the other belongs to Papilionaceae, Cyperacea, Euphorbiaceae and various other angiospermic families were recorded. Weed Species from 5 different angiospermic families were recorded. The highest diversity was reported for Asteraceae family. Species diversity of IAS indicated that study area was distinctly dissimilar or unlike in diversity and unhealthy. An investigation of the habitat depicts that herbs prevail ( 11 species) followed by shrubs ( 8 species) and trees (2 species). However, major impact of these species on the indigenous flora, change in hydrology and function of ecosystems is yet to be studied. There is an urgent need to develop regional data, information on their ecology, morphology, reproductive biology, phenology and physiology for effective management and control of IAS. Present Study will helpful in further study on developing effective management and control protocol of IAS on spreading outside their natural habitat and most prominent menaces to biodiversity.
\end{abstract}

\section{ARTICLE HISTORY}

Received: 24 May 2017 Accepted: 10 August 2017

\section{Keywords:}

"Invasive alien species (IAS)",

"Asteraceae",

"Weeds",

"Plant quarantine", "TehriGarhwal".

CONTACT Digvijaysinh Rathod rddigvijay@gmail.com 9 Silviculture Division, Forest Research Institute, Dehradun, India. (C) 2017 The Author(s). Published by Enviro Research Publishers

This is an 6 Open Access article licensed under a Creative Commons Attribution-NonCommercial-ShareAlike 4.0 International License (https://creativecommons.org/licenses/by-nc-sa/4.0/), which permits unrestricted NonCommercial use, distribution, and reproduction in any medium, provided the original work is properly cited.

To link to this article: http://dx.doi.org/10.12944/CWE.12.2.21 


\section{Introduction}

The Himalaya mountain region is one of the richest and most unusual ecosystems on Earth ${ }^{1}$. Indian Himalayan region covers about an area of 4,19,873 $\mathrm{Km}^{2}$. The unique physiography, climatic conditions, soil features of the area have resulted in a mixture of habitats and a substantial biological diversity. The Himalayan region affirms approximately 8000 plant species $(47.06 \%$ of the total flowering plants of India) of which $30 \%$ are endemics among natives, $10.2 \%$ trees, $8.44 \%$ wild edibles and over $15 \%$ medicinal. The dependence of human and livestock on this rich plant diversity is long-familiar physical process since time immemorial ${ }^{2,3}$. The Tehri Dam is tallest dam in India. Tehri Dam provides common services such as food mitigation, water supply for agricultural crop cultivation, drinking water, electricity production, employment opportunity, recreational and tourisms facility in surrounding area. The utilization and subsequent changes in hydrological water body has a significantly influencing on river flow and their linked biotic and abiotic organisms. Dams are grant credentials to as having fairly large negative effects on the closely encircling natural ecosystems divesity ${ }^{4}$. In many developing countries tourism was act as revenue generate, employment opportunity to local people, improved living standards and sustainable livihood development with buildup good relationship between people and nature from conservation point of view ${ }^{5,6,7 a}$. The global trade and tourism are key factors concerned with the ecological effects of altering the environment in developing regions ${ }^{8 \mathrm{~b}, 9}$. In the last decades tourisms has rapidly originated worldwide in mountain regions. ${ }^{10,11}$. The mountain tourisms in new emerging area had negative results on wetlands, protected areas and natural area indicated by previous examines concerned to recreation ecology ${ }^{12,13}$. In past 25 years, Nepal has rapidly increased in tourism growth, the positive or negative effect of tourism ontogenesis on forest resource and alpine vegetation plant diversity has been well recorded ${ }^{14}$.

Human actions have significant determines on the dispersal of exotic plants ${ }^{15,16,17,18}$. In Central Europe, an invasion has been often outcome of interaction between biological and anthropogenic factors ${ }^{19}$. Human interruptions enhance alien extend in general $^{20}$. They are determined that the parameters in a most excellent way to justify the density of alien plants were the human growth index and imports ${ }^{21}$.
Some outcomes guided that numbers of individuals per unit area of human population and human action have crucial consequences on the plants invasions ${ }^{22,}$ 23. Biological plant invasion have charming effect on ecologist due to their substantial ecological and economical importance from the conservation threat of plant diversity point of view worldwide ${ }^{24}$. India is the $7^{\text {th }}$ largest country and one of the mega-diversity countries on globe out of 17 most biodiversityrich countries. With a various types of habitats and different environmental conditions, India is particularly susceptible to attack of invasive species of foreign origin. The sketch of invasive plants in India is now obligating immediate action in practice and also helpful for invasion plant ecology.

The biological invasion involving the entire earth threatens biodiversity, resource availability, ecosystem dynamics, and people health and country economy ${ }^{25}$.The analyses of the apportioning of invasive alien species and the kinship with existing factors furnish the chances to explore the possible factors that lead to their spatial distribution at a prominent scale ${ }^{26,27 a}$. However, seldom observe the spatial distribution analysis revolve about species with prominent consequence separately from those with miserable effects ${ }^{28,29 b}$. The scrimpy native diversity privileges to introduce invasion proposed by Elton's ${ }^{30}$.Some data-based and model based studies reports support that diversity decreased invisibility ${ }^{31,32,33,34,35}$. Investigate on the features of invasive species and the recipient spatial location is indispensable for recognizing the action of invasion ${ }^{36}$. Therefore, insufficiency of data point concerning forest invasivesis a subject of associate as this creats an off-key of complacency. Devoted research antecedence taken to be conceded to buildup detailed database in perspective of forest resources in the state and nation on scientific lines and to updating datum. If so, for this conclusion, periodical assemblage, Identification and collection of such species are needed, thus one can find out and could consider management options to prevent, or at least reduce the damaging effects of biological invasions. And this only can be possible if we have the proper knowledge about their presence in the area, thus need the base line data, and this could gather only through inventory. The objectives of the present study accomplish this research need and provide the basic information for further research in the same field. 


\section{Materials and Methods}

The present investigation was accomplished in the District Tehri Garhwal of the Garhwal Himalayan region of Uttarakhand which lies at $30^{\circ} 55^{\prime}$ to $31^{\circ} 18^{\prime}$ $N$ latitude and $78^{\circ}$ to $79^{\circ} 25^{\prime} \mathrm{E}$ longitude in Western Himalaya covering $36000 \mathrm{sq} . \mathrm{km}$. The greatest extent of the region is $180 \mathrm{~km} \mathrm{~N}$ to $S$ and $200 \mathrm{~km} \mathrm{E}$ to W. The region is highly mountainous, ranging in altitude from $300-7000 \mathrm{~m}$, therefore by considering the diverse forms of the area the widely renowned Tehri Dam site was considered as a reference point and further study was carried out at different elevations. Specifically four different sites were marked based on their regional importance showed in Fig.1, i.e. site I (Jardhar VFE), known for its luxuriant forest area, and indigenous agricultural practices, site II (Dikhol VFE), became central hub for all the social activities, followed by site III (Kuttha VFE), this site became central point for the dam site seeing and tourism purposes and site IV (Saundkoti VFE) valuable natural site, as no any human induced pressure is assumed in this site. The concept of village forest exist in the study area, i.e., Tehri, from time immemorial as the forest were aligned to certain villages upto a certain radial distance to meet the bonafied needs and requirements of the village people. The geo-coordinates of each sites has been also recorded by using Global Positioning System (GPS) that are following:

\section{Sites $\quad$ Latitude (N) Longitude (E) Altitude ( $\mathrm{m}$ asl )}

\begin{tabular}{llll}
\hline Site I & $30^{\circ} 20^{\prime} 23^{\prime \prime}$ & $78^{\circ} 20^{\prime} 05^{\prime \prime}$ & $1650 \mathrm{~m}$ \\
Site II & $30^{\circ} 20^{\prime} 21^{\prime \prime}$ & $78^{\circ} 20^{\prime} 21^{\prime \prime}$ & $1570 \mathrm{~m}$ \\
Site III & $30^{\circ} 23^{\prime} 16^{\prime \prime}$ & $78^{\circ} 27^{\prime} 23^{\prime \prime}$ & $1220 \mathrm{~m}$ \\
Site IV & $30^{\circ} 20^{\prime} 26^{\prime \prime}$ & $78^{\circ} 25^{\prime} 02^{\prime \prime}$ & $1630 \mathrm{~m}$ \\
\hline
\end{tabular}

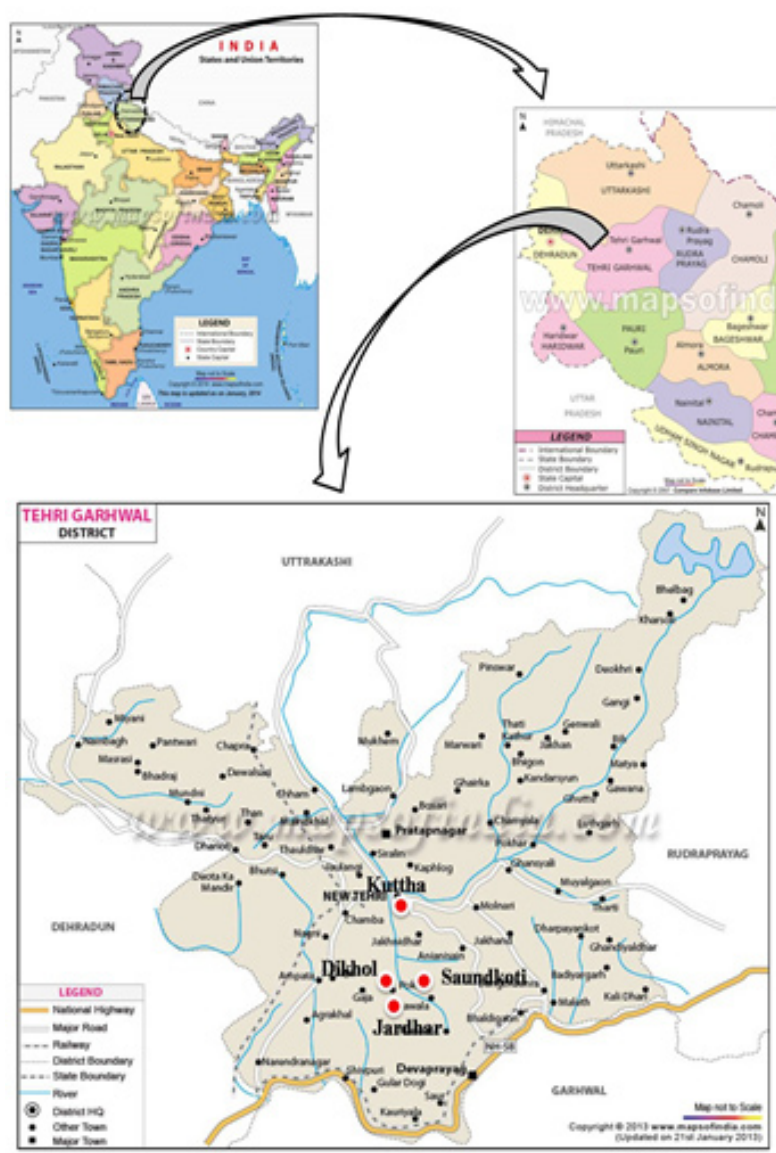

Fig. 1: Study Sites 


\section{Methods}

\section{A List Of Weed / Exotic / Invasives Of The Country}

Before starting inventory for FIS in the site, secondary data was collected by preparing literature survey, list of weeds/ exotics/ invasives of the country have been prepared as per GIS database www.issg.org/global $2007^{37}$, Negi and Hajra $2007^{38}$, Reddy $2008^{39}$, Biswas and Jain $2003^{40}$, Sankaran and Sreenivasan $2001^{41}$, Plant Quarantine report and Plant Quarantine list ${ }^{42}$. The data related to existing invasives of the sites was further gathered by critiquing the literature, research papers, working plan of the District, related flora of the site and explore the review of Biswas Sas 1985 and $1994^{43,44}$, Bhattacharya and Goel $1982^{45}$, Badoni and Bhatt $1993^{46}$, Goel and Bhattacharya $1981^{47}$, and Uniyal et. al., $1995^{48}$.

Reconnaissance surveys of the areas were carried out for the occurrence of Forest Invasive species. The available populations were studied using the random quadrate method ${ }^{49}$.The field layout of sample plots was indicated in fig. 2 along with various size of quadrate A, B, C for trees, shrubs and herbs field data enumeration. The study was carried out by laying out 50 quadrates (Fig.2) on each site. Thus a total 200 sample plot was laid out in all four sites. The herbarium samples along with camera photographs of the various plant species were collected.

The plant species found and recorded in the study sites were identified with the help of the available concerned site specific Floras, Forest flora of the Chakrata, Dehradun and Sahanpur Forest Divisions, Uttar Pradesh by Knajilal, U.P. ${ }^{50}$ and Flora of the District Garhwal Northwest Himalaya by Gaur, R.D. ${ }^{51}$ etc.).Thoroughly identification of the material was done by consulting the material with authentic specimen sheets at, DD Herbarium of FRI, Botanical Survey of India, Northern Circle, Dehradun. Final checklist of the site was cross-checked with the list of Invasive Alien Species list of IUCN for the country for the recognition of the site specific Forest Invasive Species, resulting in the form of the FIS checklist.

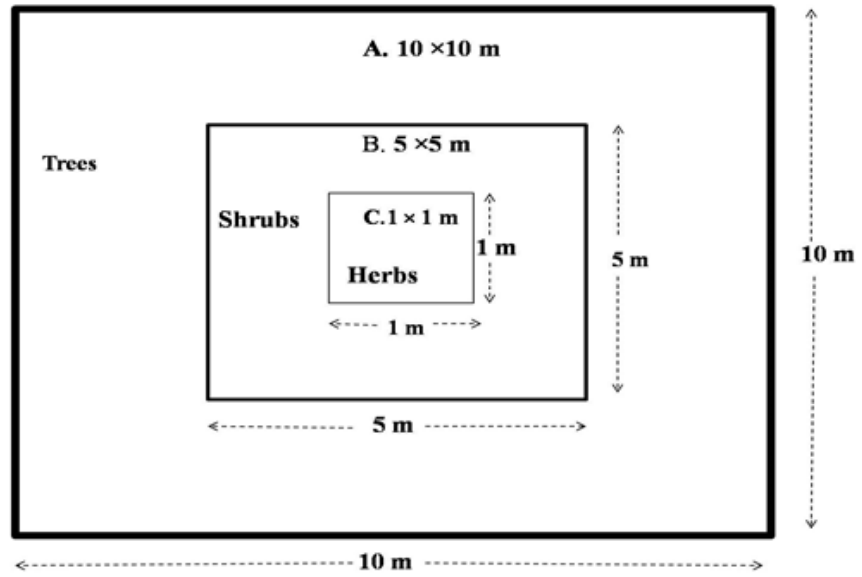

Fig. 2: Field Layout of Sample Plot

\section{Result}

The plant diversity of Forest Invasive Species of all three life form (tree, shrub and herb) and the potential weed species which could become invasives in the study area is given in Table-I,II,III,IV; Fig. III \& IV. Seventy five (75) Forest Invasive Species (FIS) and forty seven (47) weed species which could become potential invasives were invantorized from the area (Table-III and IV). Among the 75 FIS, 12 species belonging from Asteraceae, 7 species from Poaceae, 7 species of Solanaceae, 5 species of Lamiaceae, followed by four species of each Ranunculaceae and Polygonaceae while the other belongs to Papilionaceae, Cyperacea, Euphorbiaceae and various other angiospermic families were recorded. Habitat analysis of FIS showed that highest percentage of plant diversity was herbs $(81.33$ $\%$ ), shrubs (17.33\%) and Tree species (1.34\%). Whereas, plant diversity among the weed species observed in study sites was maximum belongs to angiospermic family Poaceae.

Data presented in Table I reveals the maximum 
invasion proportion in tree layer is reported in site II (Dikhol VFE) followed by site III (Kuttha VFE), and then site I (Jardhar VFE) (Table I). In site I (Jardhar VFE), the less invasion may be due to higher

Table 1: Forest Invasive Species account of the study sites

\begin{tabular}{lcccc}
\hline Category & I (Jardhar) & II (Dikhol) & III (Kuttha) & IV (Saundkoti) \\
\hline Invasive tree species & 1 & 1 & 1 & 0 \\
Invasive shrub species & 11 & 6 & 6 & 6 \\
Invasive herb species & 37 & 38 & 34 & 21 \\
Invasives total diversity & 49.0 & 45.0 & 41.0 & 27.0 \\
(No. of species) & & & & \\
\hline
\end{tabular}

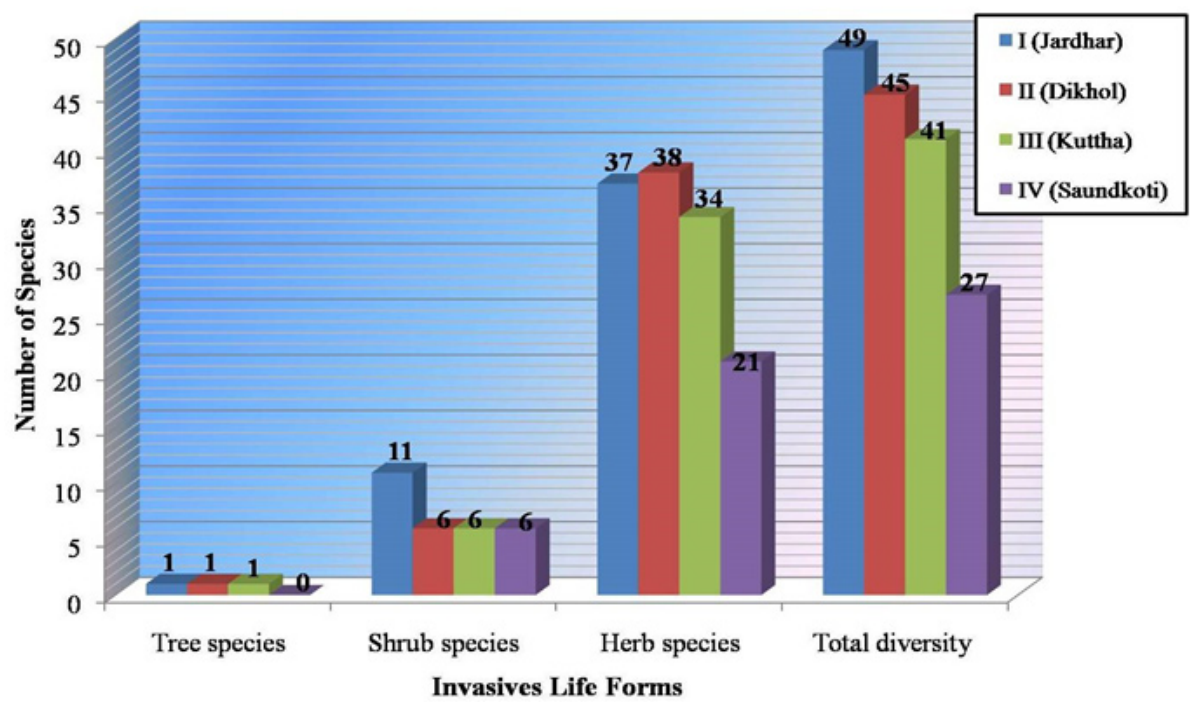

Fig. 3: FSI account of the study sites

diversity of invasives was recorded for site I (49 species), followed by site II (45 species), site III (41 species) and least invaded site was IV (27 species).

The maximum number of FIS belongs to family Asteraceae (16\%), followed by Poaceae and Solanaceae ( $9 \%$ each), Lamiaceae $(7 \%)$, Polygonaceae and Ranunculaceae $(5 \%)$ whereas other angiospermic families constitute between $(4-1 \%)$ respective dominance irrespective to other recorded families as given in Table II.

\section{Discussion}

For the present research context Dam site was considered as a reference point, and this have been widely observed that disturbed habitats are more prone to invasion. The present study observed that the cumulative effects of dam construction activities resulted in greater amount of invasion in nearby areas, whether it is forest, agriculture, wasteland, and village common land etc.Similar study was carried out in Arizona, Colorado and eastern Oregon arid area, the permanent water availability has promote the growth invasion of exotic species such as Tamarix that flourish in such considerations ${ }^{52}$. 53, 54. The inventorization carried out for the area, resulted that the forest ecosystem of four villages have similar native species in floristic composition except for dominant species while a single invasive, Euphorbia royleana is reported from the tree layer of the ecosystem. Site IV (Saundkoti village forest ecosystem) is free from this invasive because less anthropogenic disturbance in site like very few people in village carried out agriculture practices and an area is rich in native species diversity.

Level of invasion varies in all the sites, maximum 
Table 2: Dominating FIS families of the study area

\begin{tabular}{llllll}
\hline Family & $\begin{array}{l}\text { No of } \\
\text { species }\end{array}$ & $\begin{array}{l}\text { Dominance of } \\
\text { family (\%) }\end{array}$ & Family & $\begin{array}{l}\text { No of } \\
\text { species }\end{array}$ & $\begin{array}{l}\text { Dominance of } \\
\text { family (\%) }\end{array}$ \\
\hline Asteraceae & 12 & 16.00 & Brassicaceae & 1 & 1.33 \\
Solanaceae & 7 & 9.33 & Cannabinaceae & 1 & 1.33 \\
Poaceae & 7 & 9.33 & Caryophyllaceae & 1 & 1.33 \\
Lamiaceae & 5 & 6.67 & Chenopodiaceae & 1 & 1.33 \\
Polygonaceae & 4 & 5.33 & Cleomaceae & 1 & 1.33 \\
Ranunculaceae & 4 & 5.33 & Commelinaceae & 1 & 1.33 \\
Cyperaceae & 3 & 4.00 & Crassulaceae & 1 & 1.33 \\
Euphorbiaceae & 3 & 4.00 & Cuscutaceae & 1 & 1.33 \\
Fabaceae & 3 & 4.00 & Fumariaceae & 1 & 1.33 \\
Rosaceae & 3 & 4.00 & Nyctaginaceae & 1 & 1.33 \\
Amaranthaceae & 2 & 2.67 & Tiliaceae & 1 & 1.33 \\
Apiaceae & 2 & 2.67 & Linaceae & 1 & 1.33 \\
Malvaceae & 2 & 2.67 & Papavaraceae & 1 & 1.33 \\
Oxalidaceae & 2 & 2.67 & Verbenaceae & 1 & 1.33 \\
Rubiaceae & 2 & 2.67 & & & \\
\hline
\end{tabular}

Table 3: FIS diversity of the study area, Site 1 -Jardhar(I), Site 2 -DikhoI(II), Site 3 Kuttha(III), Site 4-Saundkoti(IV)

\begin{tabular}{|c|c|c|c|c|c|c|c|}
\hline S.No & Species & Family & I & II & III & IV & Habit \\
\hline 1 & Achyranthes asperaL. & Amaranthaceae & + & + & + & + & $\mathrm{H}$ \\
\hline 2 & Anaphalis busua Buch.Ham ex D.Don DC & Asteraceae & + & - & + & - & $\mathrm{H}$ \\
\hline 3 & Apludamutica, L. & Poaceae & + & + & + & - & $\mathrm{H}$ \\
\hline 4 & Argemone mexicana L. & Papavaraceae & + & + & + & + & $\mathrm{H}$ \\
\hline 5 & Arundinella nepalensisTrinius & Poaceae & + & - & - & - & $\mathrm{H}$ \\
\hline 6 & Ageratum conyzoides L. & Asteraceae & - & + & + & + & $\mathrm{H}$ \\
\hline 7 & Amaranthus spinosus $L$ & Amaranthaceae & - & - & + & - & $\mathrm{H}$ \\
\hline 8 & Blainvilleaa cmella (L.) Philipson & Asteraceae & + & - & - & - & $\mathrm{H}$ \\
\hline 9 & Bupleurum hamiltonii Balakrishnan & Apiaceae & + & - & - & - & $\mathrm{H}$ \\
\hline 10 & Biden spilosa L. & Asteraceae & - & + & + & + & $\mathrm{H}$ \\
\hline 11 & Bistorta amplexicaulis (D.Don) Greene & Polygonaceae & - & + & - & - & $\mathrm{H}$ \\
\hline 12 & Boerhavia diffusa L. & Nyctaginaceae & - & + & + & + & $\mathrm{H}$ \\
\hline 13 & Clematis gouriana Roxb. ex DC. & Ranunculaceae & + & + & + & + & $\mathrm{S}$ \\
\hline 14 & Clematis montana Buch.-Ham. ex DC & Ranunculaceae & + & - & - & + & S \\
\hline 15 & Cleome viscosa $\mathrm{L}$. & Cleomaceae & + & - & - & + & $\mathrm{H}$ \\
\hline 16 & Cuscuta reflexa Roxb & Cuscutaceae & + & - & - & - & $\mathrm{H}$ \\
\hline 17 & Cymbopogon martinii (Roxb) W.Watson & Poaceae & + & - & - & - & $\mathrm{H}$ \\
\hline 18 & Cynodon dactylon L. Persoon & Poaceae & + & + & + & + & $\mathrm{H}$ \\
\hline 19 & Cyperus niveus Retz. & Cyperaceae & + & - & - & - & $\mathrm{H}$ \\
\hline 20 & Cannabis sativa L. & Cannabinaceae & - & + & - & - & $\mathrm{H}$ \\
\hline 21 & Chenopodium album L. & Chenopodiaceae & - & + & - & - & $\mathrm{H}$ \\
\hline 22 & Commelina benghalensis $\mathrm{L}$. & Commelinaceae & - & + & + & + & $\mathrm{H}$ \\
\hline 23 & Datura metel L & Solanaceae & - & + & + & - & $\mathrm{H}$ \\
\hline 24 & \multicolumn{2}{|c|}{ Delphinium denudatumWallich ex Hook.f. \& Thomson } & \multicolumn{3}{|c|}{ Ranunculaceae } & + & - \\
\hline
\end{tabular}


Desmodium triflorum (L.)DC

Eupatorium glandulosum H.B.K.

Euphorbia hirta L.

Euphorbia royleanaBoissier.

Echinochloa colona (L.) Link

Fimbristylis falcata (Vahl) Kunth

Fumaria indica (Haussknecht) Pugsley

Gerbera gossypina (Royle)G. Beauv.

Heteropogon contortus

L. Beauv. ex Roemer \& Schultes Indigofera heterantha Wallich ex

Brandis, Syn I. gerardiana (Wallich ex Baker) Ali

\section{Koenigiadelicatula (Meisn.) Hara}

Syn Polygonum delicatulum Meisn

Kyllinga brevifolia Rottboell

Lantana camara L.

Leucas lanataBenth

Micromeria biflora (Buch.-Ham.

exD.Don) Benth

Nepeta graciliflora Benth

Nicotiana plumbaginifolia Viviani

Ocimumbasilicum L.

Oxalis corniculata L.

Oxalis dehradunensis Raizada

Origanum vulgare $\mathrm{L}$.

Parthenium hysterophorus $\mathrm{L}$.

Pavetta indica L.

Physalis peruviana $\mathrm{L}$.

Polygonum plebeium R.Br.

Reinwardtia indica Dumortier

Rosa brunonii Lindley

Rubia cordifolia L.

Rubus ellipticus Smith.

Rubus niveus Thunb.

Rumex hastatus D.Don

Ranunculus sceleratus $\mathrm{L}$.

Ricinus communis $\mathrm{L}$

Rorippa indica (L.) Hiern

Saccharum spontaneum $\mathrm{L}$.

Sedum multicaule Wallich ex Lindley

Senecio nudicaulis Buch.-Ham.exD.Don

Solanum anguiviLam

Solanum nigrum L.

Solanum verbascifoliumauct.pl.

Sonchusolearecus L

Selinumcandollii DC

Sida rhombifolia L.

Solanum surattense Burm.f.

SynS. xanthocarpum,
Fabaceae

Asteraceae

Euphorbiaceae

Euphorbiaceae

Poaceae

Cyperaceae

Fumariaceae

Asteraceae

Poaceae

Fabaceae

$\begin{array}{lllll}- & - & + & - & \mathrm{H} \\ + & + & + & + & \mathrm{H} \\ + & + & + & + & \mathrm{H} \\ + & + & + & - & \mathrm{T} \\ + & + & - & - & \mathrm{H} \\ + & - & - & - & \mathrm{H} \\ + & - & - & - & \mathrm{H} \\ + & - & - & + & \mathrm{H} \\ + & + & - & - & \mathrm{H} \\ + & & & & \\ + & - & - & - & \mathrm{S}\end{array}$

$\begin{array}{llllll}\text { Polygonaceae } & + & - & - & - & \mathrm{H} \\ \text { Cyperaceae } & - & - & + & - & \mathrm{H} \\ \text { Verbenaceae } & + & + & + & + & \mathrm{S} \\ \text { Lamiaceae } & + & - & - & + & \mathrm{H} \\ \text { Lamiaceae } & + & + & - & - & \mathrm{H} \\ \text { Lamiaceae } & + & & & & \\ \text { Solanaceae } & - & - & + & - & \mathrm{H} \\ \text { Lamiaceae } & + & + & - & - & \mathrm{H} \\ \text { Oxalidaceae } & - & + & + & + & \mathrm{H} \\ \text { Oxalidaceae } & - & + & + & + & \mathrm{H} \\ \text { Lamiaceae } & - & - & + & - & \mathrm{H} \\ \text { Asteraceae } & + & + & + & + & \mathrm{H} \\ \text { Rubiaceae } & + & + & - & - & \mathrm{S} \\ \text { Solanaceae } & + & + & - & - & \mathrm{H} \\ \text { Polygonaceae } & - & + & + & - & \mathrm{H} \\ \text { Linaceae } & + & + & + & + & \mathrm{H} \\ \text { Rosaceae } & + & + & + & + & \mathrm{S} \\ \text { Rubiaceae } & + & + & + & + & \mathrm{H} \\ \text { Rosaceae } & + & + & + & + & \mathrm{S} \\ \text { Rosaceae } & + & - & - & - & \mathrm{S} \\ \text { Polygonaceae } & + & + & + & + & \mathrm{H} \\ \text { Ranunculaceae } & - & + & - & - & \mathrm{H} \\ \text { Euphorbiaceae } & - & + & + & - & \mathrm{S} \\ \text { Brassicaceae } & - & + & + & - & \mathrm{H} \\ \text { Poaceae } & + & + & + & - & \mathrm{H} \\ \text { Crassulaceae } & + & - & + & - & \mathrm{H} \\ \text { Asteraceae } & + & - & + & + & \mathrm{H} \\ \text { Solanaceae } & + & - & - & - & \mathrm{S} \\ \text { Solanaceae } & + & + & + & + & \mathrm{H} \\ \text { Solanaceae } & + & - & - & - & \mathrm{S} \\ \text { Asteraceae } & + & + & + & + & \mathrm{H} \\ \text { Apiaceae } & - & + & - & - & \mathrm{H} \\ \text { Malvaceae } & - & + & + & - & \mathrm{H} \\ & & & & & \\ \text { Solanaceae } & - & + & - & - & \mathrm{H}\end{array}$


Schrader \&Wendland

69 Stellaria media (L.) Villars

70 Syndrellaspp.

71 Tridax procumbensL.

72 Triumfettar homboidea Jacquin

73 Trifolium repens $\mathrm{L}$.

74 Urenal obata L.

$75 \quad$ Xanthium strumarium $\mathrm{L}$

$\begin{array}{llllll}\text { Caryophyllaceae } & - & + & + & - & \mathrm{H} \\ & - & + & + & - & \mathrm{H} \\ \text { Asteraceae } & + & + & + & - & \mathrm{H} \\ \text { Tiliaceae } & + & - & - & - & \mathrm{H} \\ \text { Fabaceae } & - & + & - & - & \mathrm{H} \\ \text { Malvaceae } & + & - & - & - & \mathrm{S} \\ \text { Asteraceae } & - & + & + & + & \mathrm{S}\end{array}$

(+)Present; (-) Absent

Table 4: Check list of weedy species of the study area

\begin{tabular}{|c|c|c|c|}
\hline S.No. & Species & Family & Habit \\
\hline 1 & Agave wightii,Drummond \& Prain & Agavaceae & S \\
\hline 2 & Ajuga bracteosa, Wallich ex Benth & Lamiaceae & $\mathrm{H}$ \\
\hline 3 & Alloteropsis cimcina (L.) Stapf & Poaceae & $\mathrm{H}$ \\
\hline 4 & Amaranthus spp. & Amaranthaceae & $\mathrm{H}$ \\
\hline 5 & Anagallis arvensis, $\mathrm{L}$. & Primulaceae & $\mathrm{H}$ \\
\hline 6 & Androsace lanuginose, Wall & Primulaceae & $\mathrm{H}$ \\
\hline 7 & Androsace umbellate (Lour.) Merrill & Primulaceae & $\mathrm{H}$ \\
\hline 8 & Apluda mutica, L. & Poaceae & $\mathrm{H}$ \\
\hline 9 & Avena sativa $\mathrm{L}$. & Poaceae & $\mathrm{H}$ \\
\hline 10 & Barleria cristata L. & Acanthaceae & $\mathrm{H}$ \\
\hline 11 & Chenopodium album, L. & Chenopodiaceae & $\mathrm{H}$ \\
\hline 12 & Chenopodium ambrosiodes, L. & Chenopodiaceae & $\mathrm{H}$ \\
\hline 13 & Cichorium intybus, L. & Asteraceae & $\mathrm{H}$ \\
\hline 14 & Commelina benghalensis, L. & Commelinaceae & $\mathrm{H}$ \\
\hline 15 & Crotalaria prostrate, Rottler ex Willd & Papilionaceae & $\mathrm{H}$ \\
\hline 16 & $\begin{array}{l}\text { Cynoglossum zeylanicum } \\
\text { (VahlexnbHornem) Thunb.ex Lehmann }\end{array}$ & Boraginaceae & $\mathrm{H}$ \\
\hline 17 & Cyperus rotundus & Poaceae & $\mathrm{H}$ \\
\hline 18 & Desmodium triflorum (L.) DC & Papilionaceae & $\mathrm{H}$ \\
\hline 19 & Dicliptera spp. & Acanthaceae & $\mathrm{H}$ \\
\hline 20 & Digitaria sanguinalis (L.) Scop & Poaceae & $\mathrm{H}$ \\
\hline 21 & Drymaria cordata (L.) Willd & Caryophyllaceeae & $\mathrm{H}$ \\
\hline 22 & Eragrostis spp. & Poaceae & $\mathrm{H}$ \\
\hline 23 & Euphorbia hypericifolia, L & Euphorbiaceae & $\mathrm{H}$ \\
\hline 24 & Fimbristylis falcate (Vahl) Kunth & Cyperaceae & $\mathrm{H}$ \\
\hline 25 & Fumariaindica, (Haussknecht) Pugsley & Fumariaceae & $\mathrm{H}$ \\
\hline 26 & Galinsoga ciliate (Raf.Schm.)Blake & Asteraceae & $\mathrm{H}$ \\
\hline 27 & Geranium nepalense, Sweet & Geraniaceae & $\mathrm{H}$ \\
\hline 28 & Hedyotis corymbosa (I.) Lam & Rubiaceae & $\mathrm{H}$ \\
\hline 29 & Kyllinga spp. & Cyperaceae & $\mathrm{H}$ \\
\hline 30 & Lathyrus sativus, L. & Papilionaceae & CS \\
\hline 31 & Leucas lanata,Benth & Lamiaceae & $\mathrm{H}$ \\
\hline 32 & Micromeria biflora Buch.-Ham.ex D Don. Benth & Lamiaceae & $\mathrm{H}$ \\
\hline 33 & Nepeta graciliflora, Benth & Lamiaceae & $\mathrm{H}$ \\
\hline 34 & Oplismenus compositus (L.)P.Beauv & Poaceae & $\mathrm{H}$ \\
\hline 35 & Peristrophe speciosa (Roxb) Nees & Acanthaceae & $\mathrm{S}$ \\
\hline 36 & Pogonantherum spp. & Poaceae & $\mathrm{H}$ \\
\hline 37 & Polygala chinensis, L. & Polygonaceae & $\mathrm{H}$ \\
\hline 38 & Rumex hastatus,D.Don & Polygonaceae & $\mathrm{H}$ \\
\hline
\end{tabular}




\author{
Rungia parviflora, Nees \\ Setaria gluca (L.) P.Beauv \\ Sileneconoidea, L. \\ Sporobolus diander (Retz) P. Beauv \\ Stellaria media (L.) Villars \\ Torenia cordifolia, Roxb. \\ Triumfetta annua, L. \\ Trium fettapilosa, Roth \\ Vernonia cinerea (L.) Lessing
}

$\begin{array}{ll}\text { Acanthaceae } & \mathrm{H} \\ \text { Poaceae } & \\ \text { Caryophyllaceae } & \mathrm{H} \\ \text { Poaceae } & \mathrm{H} \\ \text { Caryophyllaceeae } & \mathrm{H} \\ \text { Scrophulariaceae } & \mathrm{H} \\ \text { Tiliaceae } & \mathrm{H} \\ \text { Tiliaceae } & \mathrm{S} \\ \text { Asteraceae } & \mathrm{H}\end{array}$

*H-Herb, S-Shrub
$\mathrm{H}$

$\mathrm{H}$

$\mathrm{H}$

$\mathrm{H}$

$\mathrm{H}$

$S$

$\mathrm{H}$

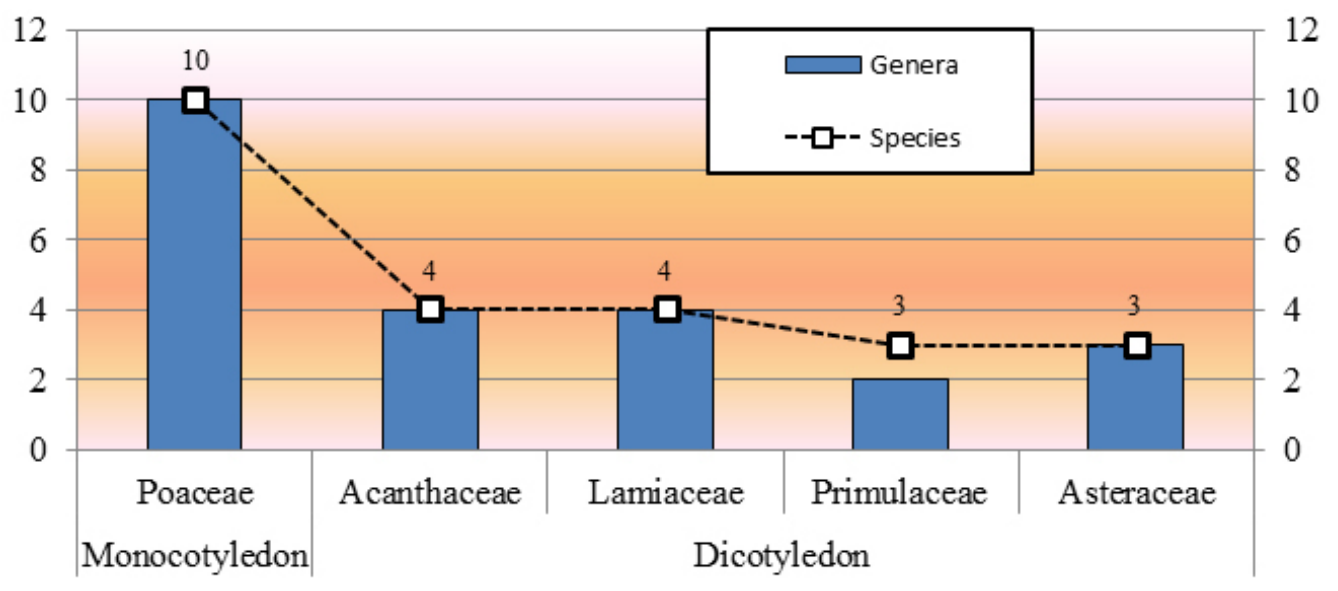

Fig. 4: Dominnent weedy species familyn of the study area

diversity of native species, invasives though present but could not get accommodated or spread their area of occupancy, thus proportion of invasion is least among all three invaded sites II (Dikhol), III (Kutta), I (Jardhar) (Fig I). Our finding agree with the protocol designed to distinguish between species that induce higher, medium, lower, or undistinguished negative affect to indigenous biodiversity within the region, state or nation of interest ${ }^{55}$.

While disturbance in site II attributed for developing empty niche which in turn promoted invasion in the area. Similar problem is also attributed in site III, where habitat disturbance is very high due to the close vicinity of Tehri hydroelectric dam. Another important reason of invasion is the association of Pinus roxburghii in all the affected sites, as it is associated with the acidity in soil, where invasives like Euphorbia royleana can flourish ${ }^{56}$ and the present study reveals that site III (Kuttha) is Pinus dominated might be create a favorable condition to growth of invasive species and hence, proportion of invasion this site is maximum in comparison to the other study sites.
Though Pinus roxburghii is also reported in site IV (Saundkoti), but as per field observations this place is situated at higher elevation and far from the reference point as a disturbing factor, dominated by Quercus leucotrichophora, Rhododendron arboreum and Cedrus deodara, which likely to be assumed for prohibition of the growth of Euphorbia royleana in the forest.

The invaded environment was providing desirable condition to invasion of species from outset, that likewise, the invasive species has the potentiality of obtruding upon that environment without any intrinsic ecological or evolutionary changes being necessitated. Therefore, wherever space is found to be free from the natives, invasives encroached those as revealed from the study and also supported by the empty niche hypothesis proposed by Elton ${ }^{57}$.

Site II and III are equally affected by invasion of shrubaceous flora indicating a high disturbances level and invasion proportion. Both the phenomena are related to each other thus supporting the theory that more disturbances will promote more invasions. Invasion by herbaceous invasive species was 
almost equal in all the sites as the herbs establish easily irrespective of shrub or tree species and their seedlings. And this is also proven by the inventory that maximum numbers of invasive are from herbs. In a number of cases, intense biotic interference (as in Dikhol, Saundkoti and Kuttha forest) does not permit the native scrub vegetation to progress any further whereas invasive herbs and few of shrubs by virtue of their specific traits gradually make thickets in these threatened areas. Another result of the biotic interference is the occurrences of blank covers over large areas, which eventually become the home of invasive shrubs, annual and perennial herbs.

Studies reveal that Asteraceae was the higher number (12) of species than other families thus it is most dominant family in study area. It is due to the fact that the members of the family are best equipped to the study area, possess best traits among all. The family is followed by invasives belonging to Poaceae and Solanaceae. The representative of the families are of herbaceous life form having short life cycle, few are perennials, thus possessing better opportunities for their survival and better growth and thus encroach the area without any natural hindrance. ${ }^{58} \mathrm{Kumari}$ et al also carried out study on a preliminary survey of invasive alien angiosperms of Rohilkhand region (U.P), India, revealed that maximum species (21) was from the family Asteraceae, Amaranthaceous (7), Euphorbiaceae (5), Papilionaceae (4) and Caesalpiniaceae (4) respectively ${ }^{56}$. This conclude that the heightening a number of invasive alien species increased with disturbance and may affect the native diversity threat. This study will help in carrying out further research work on it; and also helpful support to ecologist, agriculturist, forest and concerned stack holder to understand the pattern of distribution of plant in area. Assist as conservation of natural resources against step-down of quality and quantity of resources.

\section{Acknowledgements}

The authors are grateful to Forest Research Institute authorities for providing necessary facilities. The First author (Arti Khanduri) thankful to all the Tehri Village people and her classmates for support during field study.

\section{References}

1. Salick, J., Zhendong, F. and Byg, A. Eastern Himalayan alpine plant ecology, Tibetan ethnobotany, and climate change, Global Environmental Change, 19 (2): 147-155 (2009)

2. Dhar, U., Rawal, R. S. and Samant, S. S. Structural diversity and representativeness of forest vegetation in a protected area of Kumaun Himalaya, India: implications for conservation, Biodiversity \& Conservation, 6 (8): 1045-1062 (1997)

3. Rawat V.S. and Chandra, J. Vegetational Diversity Analysis across Different Habitats in Garhwal Himalaya, JournalofBotany, Vol. 2014 (Article ID 538242): 5 (2014)

4. New, T and Xie, Z. Impacts of large dams on riparian vegetation: applying global experience to the case of China's Three Gorges Dam, BiodiversConserv , 17:31493163 (2008)

5. WTO (World Tourism Organization). Tourism's potential as a sustainable development strategy. Madrid:World Tourism Organization

\section{(2005)}

6. Gurung, C.P, DeCoursey, M.A., Too much too fast: lessons from Nepal's Lost Kingdom of Mustang. In: Godde PM, Price MF, Zimmermann FM, editors. Tourism and development in mountain regions. Wallingford: CABI Publishing, p. 239-54 (2000)

7. aBrohman, J. New directions in tourism for third world development. Ann Tour Res, 23: 48-70 (1996)

8. ${ }^{\mathrm{b} B r o h m a n, ~ J . ~ N e w ~ d i r e c t i o n s ~ i n ~ t o u r i s m ~ f o r ~}$ third world development. Ann Tour Res, 23: 48-70 (1996)

9. Hulme, P.E. Trade, transport and travel: managing invasive species pathways in an era of globalization. J.Appl.Ecol.46:10-18 (2009)

10. Moss, L, Godde, P.M. Strategy for future mountain tourism. In: Godde PM, Price MF, Zimmermann FM, editors. Tourism and development in mountain regions. Wallingford: CABI Publishing, p. 323-38 (2000)

11. Price, M.F. Patterns of the development of 
tourism in mountain environments. Geo Journal, 27:87-96 (1992)

12. Stevens, S. Tourism and deforestation in the Mt Everest region of Nepal. Geogr J, 169: 255-7 (2003)

13. Buntaine, M.T., Mullen, R.B., and Lassoie, J.P. Human use and conservation planning in Alpine areas of Northwestern Yunnan, China. Environ Dev Sustain, 9:305-24 (2006)

14. Stevens,. S. Tourism and Deforestation in the Mt. Everest Region ofNepal. TheGeographicalJournal, 169 (3): 255-277 (2003)

15. Elton, C.S .The Ecology of Invasions by Animals and Plants. Methuen, London (1958)

16. Burke, M.J.W. and Grime, P. An experimental study of plant community invasibility. Ecology, 77: 776-790 (1996)

17. Mack, M.C. \&D'Antonio, C.M.. Impacts of biological invasions on disturbance regimes. Trends in Ecology and Evolution, 13: 195-198 (1998)

18. Sax, D. F., Gaines, S. D., and Brown, J. H. Species invasions exceed extinctions on islands worldwide: a comparative study of plants and birds. AmericanNaturalist160: 766-783 (2002)

19. Kowarik, I. Human agency in biological invasions: secondary releases foster naturalization and population expansion of alien plant species. Biological Invasions, 5: 293-312 (2003)

20. Rodgers, J.C. \& Parker, K.C. Distribution of alien plant species in relation to human disturbance on the Georgia Sea Islands. DiversityandDistributions, 9: 385-398 (2003)

21. Vila, M. \& Pujadas, J. Land use and socio economic correlates of plant invasions in European and North African countries. BiologicalConservation, 100: 397-401 (2001)

22. Pyiek, P., Kopecky, M., Jaroiik, V. \&Kotkova, $P$. The role of human density and climate in the spread of Heracleummantegazzianum in the Central European landscape. Diversity and Distributions, 4: 9-16 (1998)

23. Myers, J. and Bazely, D. Ecology and control of introduced plants. Cambridge University
Press, Cambridge (2003)

24. Reichard, S.H., and White, .P. Invasion biology: an emerging field of study. Ann Mo Bot Gard, 90:64-66 (2003)

25. Ricciardi, A., Steiner, WWM., Mack, R.N. and Simerloff, .D. Towards a global information system for invasive species. Bioscience50 (3): 239-244 (2000)

26. Whittaker, R.H. Species diversity in land communities. EvolutionaryBiology, 10: 1-67 (1977)

27. ${ }^{a}$ Dark, S.J. The biogeography of invasive alien plants in California: an application of GIS and spatial regression analysis. Diversity and Distributions, 10:1-9 (2004)

28. Levine, J. \&D'Antonio, C.M. Elton revisited: a review of evidence linking diversity and invasibility. Oikos, 87:15-26 (1999)

29. ${ }^{b}$ Dark, S.J. The biogeography of invasive alien plants in California: an application of GIS and spatial regression analysis. Diversity and Distributions, 10:1-9 (2004)

30. Elton, C.S. The ecology of invasions by animals and plants, 2nd edn. Methuen, London (1958)

31. Levine, J.M. Species diversity and biological invasions: relating local process to community pattern. Science, 288: 852-854 (2000)

32. Naeem, S., Knops, J.M.H., Tilman, D., Howe, K.M., Kennedy, T. \& Gale, S. Plant diversity increases resistance to invasion in the absence of covarying extrinsic factors. Oikos, 91: 97-108 (2000)

33. Hector, A., Dobson, K., Minns, A., BazeleyWhite, E. and Lawton, J.H. Community diversity and invasion resistance: an experimental test in a grassland ecosystem and a review of comparable studies. Ecological Research, 16: 819-831 (2001)

34. Kennedy, T.A., Naeem, S., Howe, K.M., Knops, J.M.H., Tilman, D. and Reich, P. Biodiversity as a barrier to ecological invasion. Nature, 417: 636-638 (2002)

35. Van Ruijven, J., de Deyn, G.B. \&Berendse, F. Diversity reduces invasibility in experimental plant communities: the role of plant species. EcologyLetters, 6: 910-918 (2003)

36. Vermeij, G. An agenda for invasion biology. BiologicalConservation, 78: 3-9 (1996)

37. GIS database (2007) .The Invasive Species 
Specialist Group (ISSG) .Online searchable database www.issg.org/global 2007.

38. Negi, P.S. and Hajra, P.K. Alien flora of Doon Valley, North-west Himalaya. Current Science, 92(7): 968-978 (2007)

39. Reddy, S. Catalogue of invasive alien flora of India. Life science Journal, 5(2):84-89 (2008)

40. Biswas Sas. and Jain, S.S. Invasive alien species of India and biodiversity conservation: In: National workshop on Invasive Alien Species organized by Banaras Hindu University, 18-20 August 2004 (2004)

41. Sankaran, K.V. and Sreenivasan., M.A. Status of Mikania infestation in the Western Ghats. In: Proceedings of Workshop on Alien weeds in moist tropical zones: Banes and Benefits. KFRI, India, CABIBiosciene, U.K., pp. 67-76 (2001)

42. Ministry of Agriculture, The Gazette of India, Extraordinary Part-ii-Section 3-Sub-Section (ii) New Delhi 2003. Retrieve from: http:// dbtbiosafety.nic.in/act/Plant\% 20 Quarantine $\%$ 20_order_2003.pdf

43. Biswas, Sas. Studies on the forest flora of TehriGarhwal, U.P. Introduction, plant exploration and phytogeography. Indian $\mathrm{J}$. Forestry,8 (3):199-204 (1985)

44. Biswas, Sas. Potential economic forest produces of TehriGarhwal Himalaya (U.P) with reference to the systematic studies. Higher Plants of Indian Subcontinent. 3: 281287, (1994)

45. Bhattacharya, U.C. and Goel, A.K. Studies on the Vegetation of Tehri Dam and Some Rare Plants in Garhwal Himalayas. Botanical Survey of India. Howrah. pp.1-38 (1982)

46. Badoni, A.K. and Bhatt, B.P. Addition to the Pteridophytic flora of Tehri District in GarhwalHimalya. Higher Plants of Indian Subcontinent,4: 235-242 (1993)

47. Goel, A.K. and Bhattacharya, U.C. Contribution to the Pteridophytic Flora of Tehri District (Garhwal) Indian J. For., 4:30-37 (1981)

48. Uniyal, B.P., Singh, S. and Singh, D.K. Plant Diversity in the Tehri Dam Submersible Area. BotanicalSurveyofIndia, Govt. India (1995)
49. Mishra, R. Ecology Work Book. Oxford and IBS Publishing Company, Calcutta (1968)

50. Kanjilal, .U.N. Forest Flora of the Chakrata, Dehradun and Saharnpur forest divisions, Uttar Pradesh. 3rd ed. Delhi: Manager of publications, Government of India Press (1928)

51. Gaur, R.D. Flora of the District Garhwal North West Himalaya, Transmedia: Srinagar Garhwal, India (1999)

52. Friedman, J.M, Osterkamp, W.R, Scott, M.L, Auble, G.T. Downstream eVects of dams on channel geomorphology and bottomland vegetation: regional patterns in the Great Plains. Wetlands 18:619-633 (1998)

53. Stromberg, J.C., Beauchamp, V.D., Dixon, M.D., Lite, S.J., and Paradzick, C. Importance of low-Xow and high- Xow characteristics to restoration of riparian vegetation along rivers in arid south-western United States. Freshw Biol,52:651-679(2007) doi:10.1111/j.13652427.2006.01713.x

54. Nagler, P.L, Glenn, E.P, Hinojosa-Huerta, O., Zamora, F., Howard, K., Riparian vegetation dynamics and evapotranspiration in the riparian corridor in the delta of the Colorado River, Mexico. J Environ Manage, 41(3):322335 (2008)

55. Randall, J.M., Morse, L.E., Benton, N., Hiebert, R., Lu, S. and Killeffer, T. The Invasive Species Assessment Protocol: A Tool for Creating Regional and National Lists of Invasive Nonnative Plants that Negatively Impact Biodiversity, Invasive Plant Science and Management, 1:36-49 (2008)

56. Banerjee, A. K. Shrubs in tropical forest ecosystem example from India. In: World Bank Technical Paper Number 103. The World Bank, Washington, DC, U.S.A (1989)

57. Elton, C.S. The ecology of invasions by animals and plants, 2nd edn. Methuen, London (1958)

58. Kumari, B., Singh, S.P., Singh, A.P., Kumar, R. and Verma, S. A preliminary survey of invasive alien angiosperms of Rohilkhand region (U.P.), India. Plant Archive, 16 (1): 45-50 (2016) 